\title{
Performa Produksi Telur Ayam Ketarras dan Ayam Arab Umur 28 - 40 Minggu
}

\author{
Kususiyah $^{1 *}$, Desia Kaharuddin ${ }^{1}$ dan Aditya Ananda Dwi Surnoto ${ }^{1}$ \\ ${ }^{1}$ Jurusan Peternakan, Fakultas Pertanian, Universitas Bengkulu, Jalan Raya W. R. Supratman, Kandang \\ Limun, Bengkulu, $38371 \mathrm{~A}$ \\ *Penulis korespondensi: kususiyah@unib.ac.id
}

Artikel ini diterima (received): 22 September 2020; dinyatakan disetujui (accepted): 26 Oktober 2020; terbit (published): 27 November 2020. Artikel ini dipublikasi secara daring pada https://ejournal.unib.ac.id/index.php/buletin_pt/index

\begin{abstract}
Abstrak
Penelitian ini bertujuan mengevaluasi performa produksi telur ayam Ketarras dan ayam Arab umur 28 - 40 minggu. Lima puluh ekor ayam umur 28 minggu dikelompokkan menjadi 2 kelompok sebagai perlakuan. Kelompok pertama adalah ayam Ketarras dan kelompok kedua adalah ayam Arab. Masing masing kelompok terdiri 25 ekor sebagai ulangan. Ayam dipelihara pada kandang batteray individu. Variabel yang diamati meliputi konsumsi ransum, produksi telur (butir), ukuran telur (g/butir), produksi massa telur (g/ekor), dan konversi ransum. Data yang diperoleh diuji t. Hasil uji t menunjukkan konsumsi ransum, dan konversi ransum berbeda nyata ( $t$ hitung $>\mathrm{t}$ tabel), sedangkan produksi telur (butir), ukuran berat telur (g/butir) serta produksi massa telur (g/ekor) berbeda tidak nyata (t hitung $<\mathrm{t}$ tabel). Konsumsi ransum umur 28-40 minggu ayam Ketarras 8703,04 g/ekor, sedangkan ayam Arab 7777,52 g/ekor. Produksi telur ayam Ketarras 56,12 butir/ekor, sedangkan ayam Arab 52,52 butir/ekor. Ukuran berat telur ayam Ketarras 46,7 g/butir, sedangkan ayam Arab 41,24 g/butir. Produksi massa telur ayam Ketarras 2622,16 g/ekor, sedangkan ayam Arab 2169,72 g/ekor. Konversi ransum kumulatif ayam Ketarras 3,32 sedangkan ayam Arab 3,58. Hasil penelitian dapat disimpulkan bahwa konsumsi ransum dan produksi massa telur serta ukuran berat telur ayam Ketarras umur 28 - 40 minggu lebih tinggi dengan konversi ransum lebih baik dibanding ayam Arab. Produksi telur ayam Ketarras cenderung lebih tinggi meskipun berbeda tidak nyata dibanding dengan ayam Arab.
\end{abstract}

Kata kunci: ayam arab, ayam ketaras, performa, produksi

\section{Pendahuluan}

Ayam Ketarras merupakan ayam hasil persilangan dengan komposisi genetik $75 \%$ ayam Arab dan $25 \%$ ayam Ras Petelur coklat. Diketahui kerabang telur ayam Arab berwarna putih dengan produksi yang cukup tinggi (Nataamijaya et al., 2003) dan kerabang telur ayam Ras petelur berwarna coklat dengan produksi yang tinggi. Menurut Kaharuddin et al. (2020), persilangan antara ayam Arab dan ayam Ras diharapkan dapat memunculkan efek komplementer sehingga telur yang dihasilkan berwarna putih kecoklatan seperti warna kerabang telur ayam Kampung. Persilangan ayam diharapkan akan ada efek komplementerid.
Tidak dapat dipungkiri bahwa sampai saat ini konsumen telur masih menghargai telur ayam kampung di atas telur ayam ras; hal ini terlihat bahwa harga telur ayam kampung relatif lebih tinggi dibanding harga telur ayam ras. Namun demikian ketersediaan telur ayam kampung sering tersendat sehingga beredar telur ayam Arab sebagai penggantinya. Sodak (2011) menyatakan bahwa telur ayam Arab telah banyak beredar di pasaran. Beredarnya telur ayam Arab telah membuat masyarakat menyetarakan telur ayam Arab dengan telur ayam Kampung. Hal ini dapat dilihat dari harga telur ayam Arab yang relatif sama dengan harga telur ayam Kampung. Namun demikian nampaknya tidak semua konsumen telur ayam 
kampung menyukai telur ayam Arab sebagai telur ayam Kampung. Hal ini disebabkan warna kerabang telur ayam Arab yang putih bersih; tidak seperti halnya warna kerabang telur ayam Kampung yang warna kerabangnya coklat keputihan. Persilangan ayam Arab dengan ayam Ras petelur coklat yang selanjutnya diberi nama ayam Ketarras ini dalam upaya untuk mendapatkan keturunan yang dapat menghasilkan telur dengan warna kerabang coklat keputihan seperti warna kerabang telur ayam kampung dengan tingkat produksi yang bagus.

Kaharuddin et al. (2020) telah mengevaluasi performa fase awal produksi ayam Ketarras sampai umur 28 minggu; ditunjukkan bahwa dibanding dengan ayam Arab, dewasa kelamin ayam Ketarras lebih cepat, dengan berat telur pertama lebih berat dan produksi telur lebih tinggi, konsumsi ransum tidak berbeda, namun konversi ransumnya lebih baik. Hal ini menunjukkan bahwa performa fase awal ayam Ketarras lebih baik dibanding ayam Arab yang merupakan tetuanya. Berdasarkan uraian tersebut di atas, maka potensi ayam Ketarras perlu digali lebih lanjut dengan melakukan penelitian yang mengevaluasi performanya setelah umur 28 minggu. .Penelitian ini bertujuan untuk mengevaluasi performa produksi telur ayam Ketarras dan ayam Arab umur 28-40 minggu.

\section{Bahan dan Metode}

Penelitian ini menggunakan kandang batteray individu sebanyak 50 petak, dengan ukuran per unitnya: panjang $50 \mathrm{~cm}$, lebar $23 \mathrm{~cm}$ dan tinggi $50 \mathrm{~cm}$ yang dilengkapi dengan tempat pakan dan tempat minum.
Penelitian dilaksanakan ketika ayam Ketarras dan ayam Arab betina berumur 28 minggu dan dipelihara hingga berumur 40 minggu. Sebanyak 25 ekor ayam Ketarras dan 25 ekor ayam Arab dipelihara secara individu dalam kandang batteray. Nutrisi yang diberikan mengacu pada kebutuhan ransum ayam petelur pada fase produksi, yaitu dengan kandungan Protein Kasar $17 \%$ dan Energi Metabolik $2850 \mathrm{kkal} / \mathrm{kg}$ (NRC, 1994).

Pemberian ransum dilakukan dua kali sehari yaitu pada pagi hari pukul 07.00 WIB dan sore hari pukul 16.00 WIB. Ransum diberikan sebanyak $100 \mathrm{~g} /$ ekor/hari. Air minum diberikan ad libitum. Kandungan nutrisi bahan penyusun ransum, formulasi ransum dan kandungan nutrisi ransum dapat dilihat pada Tabel 1 . dan Tabel 2.

\section{Rancangan penelitian}

Penelitian ini menggunakan 2 perlakuan dan 25 ulangan, yaitu P0: Ayam Ketarras dan P1: Ayam Arab. Setiap ulangan menggunakan 1 ekor ayam, sehingga ayam yang dibutuhkan adalah 50 ekor ayam yang ditempatkan secara acak pada kandang batterai individu.

\section{Variabel yang diamati}

Variabel yang diamati meliputi konsumsi ransum, produksi telur (butir), ukuran berat telur (g/butir), produksi massa telur (g/ekor), dan konversi ransum.

\section{Analisis data}

Data yang diperoleh ditabulasi dan dianalisis menggunakan uji $t$ dengan kepercayaan 95\% (Astuti, 2007)

\section{Pelaksanaan penelitian}

Tabel 1. Kandungan nutrisi bahan penyusun ransum

\begin{tabular}{|c|c|c|c|c|c|c|}
\hline Bahan Ransum & $\begin{array}{l}\text { PK } \\
(\%)\end{array}$ & $\begin{array}{c}\mathrm{ME} \\
\text { (kkal/kg) }\end{array}$ & $\begin{array}{l}\text { SK } \\
(\%)\end{array}$ & $\begin{array}{c}\text { Lemak } \\
(\%)\end{array}$ & $\begin{array}{l}\mathrm{Ca} \\
(\%)\end{array}$ & $\begin{array}{l}P \\
(\%)\end{array}$ \\
\hline Dedak $^{a}$ & 11,00 & 2460,00 & 12,00 & 9,78 & 0,01 & 1,30 \\
\hline Jagung $^{a}$ & 8,90 & 3321,00 & 2,50 & 2,97 & 0,02 & 0,23 \\
\hline $\mathrm{KLK}^{\mathrm{b}}$ & 33,00 & 2700,00 & 7,00 & 6,37 & 11,00 & 1,28 \\
\hline
\end{tabular}

Keterangan : a: Hartadi et al. (2005)

b: Label KLK (Konsentrat Layer Khusus) 
Tabel 2. Formulasi ransum dan kandungan nutrisi ransum

\begin{tabular}{lccccccc}
\hline Bahan Penyusun & $\begin{array}{c}\text { Proporsi } \\
(\%)\end{array}$ & $\begin{array}{c}\text { PK } \\
(\%)\end{array}$ & $\begin{array}{c}\text { ME } \\
(\mathrm{kkal} / \mathrm{kg})\end{array}$ & $\begin{array}{c}\text { SK } \\
(\%)\end{array}$ & $\begin{array}{c}\text { LK } \\
(\%)\end{array}$ & $\begin{array}{c}\text { Ca } \\
(\%)\end{array}$ & $\begin{array}{c}\text { P } \\
(\%)\end{array}$ \\
\hline Dedak & 32,00 & 3,52 & 787,20 & 3,84 & 3,13 & 0,00 & 0,42 \\
Jagung Giling & 37,00 & 3,29 & 1228,77 & 0,93 & 1,10 & 0,01 & 0,09 \\
KLK & 31,00 & 10,23 & 837,00 & 2,17 & 1,97 & 3,41 & 0,40 \\
\hline Total & 100,00 & 17,04 & 2852,97 & 6,20 & 6,20 & 3,42 & 0,90 \\
\hline
\end{tabular}

\section{Hasil dan Pembahasan \\ Konsumsi ransum}

Konsumsi ransum ayam Ketarras dan ayam Arab umur 28-40 minggu disajikan pada Tabel 3. Hasil uji t menunjukkan bahwa, konsumsi ransum ayam Ketarras dan ayam Arab pada umur 28 - 40 minggu berbeda nyata (t hitung $>$ $\mathrm{t}$ tabel). Konsumsi ransum ayam Ketarras (8703,04 g/ekor) umur 28 - 40 nyata lebih tinggi dibandingkan dengan ayam Arab $(7777,52)$. Lebih tingginya konsumsi ransum ayam Ketarras ini diduga karena produksi telur ayam Ketarras relatif lebih tinggi dibanding produksi telur ayam Arab (Tabel 4). Tabel 4. menunjukkan bahwa produksi telur selama umur 28 - 40 minggu ayam Ketarras (56,12 butir/ekor) lebih tinggi dibanding ayam Arab (52,52 butir/ekor); meskipun berbeda tidak nyata. Selain hal tersebut, ukuran berat telur (Tabel 6) ayam Ketarras $(46,7 \mathrm{~g} /$ butir) juga lebih tinggi dibanding telur ayam Arab $(41,24$ g/butir).

Diketahui ayam Ketarras memiliki genetik ayam Ras petelur sebanyak $25 \%$ yang diduga dapat memberi pengaruh terhadap lebih tingginya produksi telur dan lebih beratnya ukuran berat telur ayam Ketarras dibanding ayam Arab, sehingga konsumsi ransum pun lebih tinggi dibanding ayam Arab yang merupakan salah satu tetuanya. Diketahui bahwa ayam Ketarras adalah ayam hasil persilangan antara ayam Arras (50\% ayam Arab dan $50 \%$ ayam Ras petelur) betina dengan ayam Arab jantan (Gunawan et al., 2018). Bila dibandingkan dengan konsumsi ransum ayam Arras, Arianto (2018) mendapatkan bahwa konsumsi ayam Arras umur 28 - 40 minggu adalah 12485,05 g/ekor lebih tinggi dibandingkan konsumsi ransum ayam Arab 11696,55 g/ekor. Hal ini menunjukkan bahwa konsumsi ayam Ketarras (8703,04 g/ekor) lebih rendah dibanding tetuanya, yaitu ayam Arras (12485,05 g/ekor). Grafik konsumsi ransum ayam Ketarras dan ayam Arab disajikan pada Gambar 1. Gambar 1. menunjukkan bahwa konsumsi ransum meningkat dengan bertambahnya umur ayam. Konsumsi ransum ayam Ketarras lebih tinggi dibanding ayam Arab, hal ini karena ayam Ketarras mengandung $25 \%$ genetik ayam Ras petelur coklat.

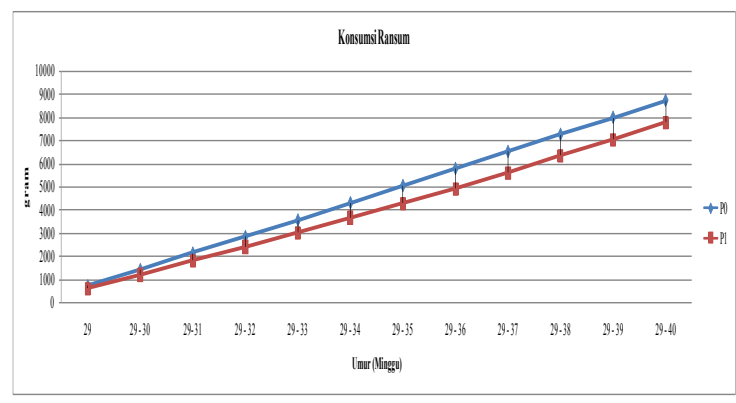

Gambar 1. Grafik konsumsi ransum ayam Ketarras (P0) dan ayam Arab (P1) umur 28-80 minggu

\section{Produksi Telur}

Produksi telur ayam Ketarras dan ayam Arab umur 28 - 40 minggu disajikan pada Tabel 4. Hasil uji t menunjukkan bahwa produksi telur ayam Ketarras berbeda tidak nyata ( $t$ hitung < t tabel) dengan ayam Arab. Dapat dilihat pada Tabel 4. bahwa produksi telur ayam Ketarras pada umur 28 - 40 minggu mencapai 56,12 butir/ekor, sedangkan ayam Arab mencapai 52,52 butir/ekor. Dapat dilihat bahwa meskipun berbeda tidak nyata, namun rataan produksi telur ayam Ketarras lebih tinggi dibandingkan ayam Arab. Produksi telur ayam Ketarras yang sedikit lebih tinggi dibanding ayam Arab diduga dipengaruhi oleh faktor genetik; ayam Ketarras memiliki komposisi genetik 75\% ayam Arab dan 25\% ayam Ras Petelur. Grafik produksi telur ayam 
Ketarras dan ayam Arab selama penelitian berlangsung dapat dilihat pada Gambar 2 .

Gambar 2. menunjukkan bahwa secara kumulatif produksi telur ayam Ketarras lebih tinggi dibanding ayam Arab. Hal ini diduga karena ayam Ketarras lebih awal mencapai dewasa kelamin dibandingkan ayam Arab. Kaharuddin et al. (2020) menyatakan bahwa ayam Ketarras mencapai dewasa kelamin pada umur 121 - 161 hari dengan rataan 135 hari; lebih cepat dibandingkan dengan umur dewasa kelamin ayam Arab yang berkisar antara 129 173 hari dengan rataan 147 hari. Selain hal tersebut, faktor genetik ayam Ketarras yang memiliki keturunan genetik $25 \%$ ayam Ras Petelur Coklat diduga menjadikan produksi telur ayam Ketarras lebih tinggi dibanding ayam Arab. Menurut Gunawan et al. (2018) ayam Ketarras memiliki genetik $75 \%$ ayam Arab dan ayam Ras petelur coklat $25 \%$.

Tabel 3. Rataan konsumsi ransum ayam Ketarras dan ayam Arab

\begin{tabular}{|c|c|c|c|c|}
\hline \multirow{2}{*}{$\begin{array}{l}\text { Umur } \\
\text { (Minggu) }\end{array}$} & \multirow{2}{*}{$\begin{array}{c}\text { Lama } \\
\text { Pengamatan } \\
\text { (Minggu) }\end{array}$} & \multicolumn{2}{|c|}{ Konsumsi Ransum } & \multirow{2}{*}{ Keterangan } \\
\hline & & P0 (Ayam Ketarras) & P1 (Ayam Arab) & \\
\hline \multicolumn{5}{|c|}{ 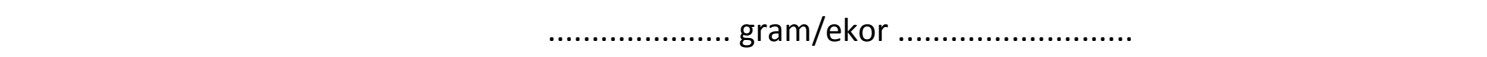 } \\
\hline $28-29$ & 1 & $697,20^{\mathrm{a}} \pm 47,23$ & $596,00^{b} \pm 95,39$ & $*$ \\
\hline $28-30$ & 2 & $1398,20^{\mathrm{a}} \pm 90,30$ & $1195,84^{\mathrm{b}} \pm 197,96$ & * \\
\hline $28-31$ & 3 & $2110,92^{\mathrm{a}} \pm 127,35$ & $1803,76^{b} \pm 293,62$ & $*$ \\
\hline $28-32$ & 4 & $2822,24^{\mathrm{a}} \pm 154,90$ & $2400,84^{\mathrm{b}} \pm 400,26$ & * \\
\hline $28-33$ & 5 & $3538,16^{a} \pm 181,65$ & $3024,00^{b} \pm 506,05$ & $*$ \\
\hline $28-34$ & 6 & $4282,96^{\mathrm{a}} \pm 199,16$ & $3661,08^{b} \pm 558,37$ & $*$ \\
\hline $28-35$ & 7 & $5027,08^{a} \pm 215,61$ & $4279,96^{b} \pm 624,45$ & $*$ \\
\hline $28-36$ & 8 & $5760,16^{a} \pm 247,77$ & $4911,76^{b} \pm 675,98$ & $*$ \\
\hline $28-37$ & 9 & $6497,72^{\mathrm{a}} \pm 277,10$ & $5591,60^{\mathrm{b}} \pm 715,90$ & $*$ \\
\hline $28-38$ & 10 & $7235,04^{a} \pm 303,06$ & $6328,44^{b} \pm 726,61$ & $*$ \\
\hline $28-39$ & 11 & $7971,28^{a} \pm 329,59$ & $7048,04^{b} \pm 757,52$ & $*$ \\
\hline $28-40$ & 12 & $8703,04^{\mathrm{a}} \pm 356,44$ & $7777,52^{b} \pm 775,34$ & $*$ \\
\hline \multicolumn{5}{|c|}{$\begin{array}{l}\text { Keterangan: }{ }^{*}=\text { berbeda nyata (t hitung }>\text { t tabel) } \\
\text { Tabel 4. Rataan produksi telur ayam Ketarras dan ayam Arab }\end{array}$} \\
\hline \multirow[t]{2}{*}{$\begin{array}{l}\text { Umur } \\
\text { (Minggu) }\end{array}$} & $\begin{array}{l}\text { Lama Pengamatan } \\
\quad \text { (Minggu) }\end{array}$ & P0 (Ayam Ketarras) & P1 (Ayam Arab) & Keterangan \\
\hline & \multicolumn{4}{|c|}{..............butir/ekor........... } \\
\hline $28-29$ & 1 & $4,88 \pm 1,18$ & $4,44 \pm 1,41$ & ns \\
\hline $28-30$ & 2 & $9,76 \pm 2,32$ & $8,80 \pm 3,00$ & ns \\
\hline $28-31$ & 3 & $14,24 \pm 3,33$ & $12,80 \pm 4,55$ & ns \\
\hline $28-32$ & 4 & $18,80 \pm 5,68$ & $16,88 \pm 6,45$ & ns \\
\hline $28-33$ & 5 & $23,04 \pm 6,94$ & $21,08 \pm 7,62$ & ns \\
\hline $28-34$ & 6 & $27,40 \pm 8,22$ & $25,40 \pm 9,35$ & ns \\
\hline $28-35$ & 7 & $32,08 \pm 8,59$ & $29,52 \pm 10,86$ & ns \\
\hline $28-36$ & 8 & $36,64 \pm 12,21$ & $33,64 \pm 9,05$ & ns \\
\hline $28-37$ & 9 & $41,68 \pm 9,37$ & $38,16 \pm 13,31$ & ns \\
\hline $28-38$ & 10 & $47,00 \pm 9,64$ & $42,84 \pm 14,03$ & ns \\
\hline $28-39$ & 11 & $51,88 \pm 9,90$ & $47,64 \pm 14,72$ & ns \\
\hline $28-40$ & 12 & $56,12 \pm 11,00$ & $52,52 \pm 15,17$ & ns \\
\hline
\end{tabular}

Keterangan: Ns = berbeda tidak nyata ( $\mathrm{t}$ hitung $<\mathrm{t}$ tabel) 


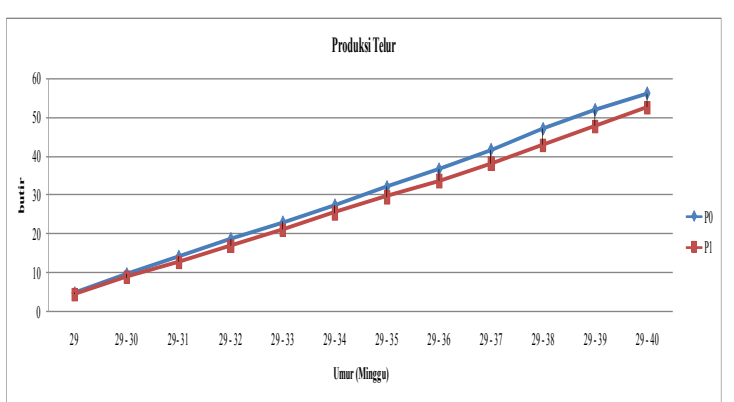

Gambar 1. Grafik produksi telur ayam Ketarras (P0) dan ayam Arab (P1) umur 28 - 40 minggu.

\section{Produksi massa telur}

Produksi massa telur ayam Ketarras dan ayam Arab umur 28 - 40 minggu disajikan pada Tabel 5. Hasil uji $t$ menunjukkan bahwa produksi massa telur ayam Ketarras berbeda nyata ( $\mathrm{t}$ hitung $>\mathrm{t}$ tabel) dengan ayam Arab. Secara kumulatif, dapat dilihat bahwa produksi massa telur pada ayam Ketarras adalah 2622,16 g/ekor, nyata lebih tinggi dibanding ayam Arab, yaitu 2169,72 g/ekor. Hal ini dapat dimengerti karena sesuai dengan produksi telur yang dihasilkan; produksi telur ayam Ketarras (56,12 butir/ekor) lebih tinggi dibanding ayam Arab (52,52 butir/ekor) (Tabel 4.). Selain hal tersebut, ukuran berat telur ayam Ketarras yang lebih tinggi dari ayam Arab (Tabel 6.) juga mempengaruhi produksi massa telur. Faktor genetik memiliki pengaruh terhadap perbedaan berat produksi dan berat perbutir telur, karena ayam Ketarras masih memiliki genetik ayam Ras Petelur Coklat sebanyak $25 \%$ yang memberi pengaruh terhadap lebih tingginya produksi telur dan lebih beratnya ukuran berat telur ayam Ketarras dibanding ayam Arab. Grafik produksi massa telur ayam Ketarras dan ayam Arab umur 28-40 minggu dapat dilihat pada Gambar 3. berikut.

Gambar 3. menunjukkan produksi massa telur meningkat dengan bertambahnya umur ayam, baik pada ayam Ketarras maupun ayam Arab. Terlihat bahwa sejak umur 29 hingga umur 40 minggu produksi massa telur ayam Ketarras lebih tinggi dibanding ayam Arab. Diketahui ayam Ketarras yang memiliki $25 \%$ genetik ayam Ras petelur diduga mempengaruhi ukuran berat telur dan jumlah produksi telur yang lebih tinggi sehingga



Gambar 2. Grafik produksi massa telur ayam Ketarras (P0) dan ayam Arab (P1) umur 28 - 40 minggu.

produksi massa telur ayam Ketarras menjadi lebih tinggi dibanding ayam Arab.

\section{Ukuran Berat telur}

Ukuran berat telur ayam Ketarras dan ayam Arab selama penelitian disajikan pada Tabel 6 . Tabel 6. menunjukkan bahwa rataan ukuran berat telur ayam Ketarras $(46,70 \mathrm{~g} /$ butir) nyata lebih tinggi dibandingkan ayam Arab $(41,24$ g/butir). Dapat dilihat pada Tabel 6. bahwa ukuran berat telur ayam Ketarras dan ayam Arab meningkat dengan bertambahnya umur ayam. Hal ini diduga karena konsumsi ransum ayam Ketarras dan ayam Arab yang juga meningkat di setiap minggunya. Ukuran berat telur saat awal bertelur cukup rendah, berat telur akan terus meningkat secara bertahap hingga umur $12-14$ bulan (Kartasudjana dan Suprijatna, 2006).

Jika dibandingkan dengan tetuanya, yaitu ayam Arras, Arianto (2018) menyatakan bahwa ukuran berat telur ayam Arras (47,98 g/butir) nyata lebih tinggi dibanding ayam Arab $(41,71$ $\mathrm{g} /$ butir). Dari perbandingan tersebut dapat dilihat bahwa pada rentang umur yang sama (28 - 40 minggu), ukuran berat telur ayam Ketarras (46,70 g/butir) lebih rendah dibanding ayam Arras $(47,98 \mathrm{~g} /$ butir). Hal ini dapat dimengerti, karena komposisi genetik ayam Ketarras $75 \%$ ayam Arab dan $25 \%$ ayam Ras sedangkan komposisi genetik ayam Arras $50 \%$ ayam Arab dan $50 \%$ ayam Ras. Hal ini sesuai dengan pernyataan Kaharuddin dan Kususiyah (2011), bahwa komposisi genetik berpengaruh nyata terhadap ukuran telur. Penelitian sebelumnya, yaitu minggu 17- 28 minggu, Kaharuddin (2020) menyatakan bahwa ukuran berat telur ayam Ketarras adalah 38,67 $\mathrm{g} /$ butir, sedangkan ayam Arab 33,63g/butir. 
Hal ini menunjukkan bahwa bertambahnya umur meningkatkan ukuran berat telur (North, 1984, Suprijatna et al., 2008).

Tabel 5. Produksi massa telur ayam Ketarras dan ayam Arab umur 28-40 minggu

\begin{tabular}{|c|c|c|c|c|}
\hline $\begin{array}{c}\text { Umur } \\
\text { (Minggu) }\end{array}$ & $\begin{array}{c}\text { Lama } \\
\text { Pengamatan } \\
\text { (Minggu) }\end{array}$ & PO (Ayam Ketarras) & P1 (Ayam Arab) & $\begin{array}{c}\text { Keteranga } \\
\mathrm{n}\end{array}$ \\
\hline \multicolumn{5}{|c|}{ 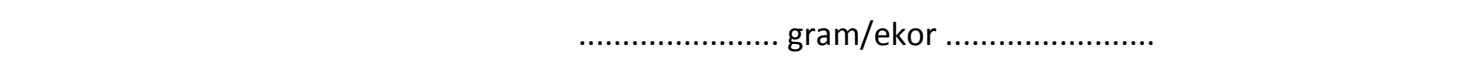 } \\
\hline $28-29$ & 1 & $217,40^{\mathrm{a}} \pm 57,84$ & $169,64^{b} \pm 54,21$ & $*$ \\
\hline $28-30$ & 2 & $436,52^{\mathrm{a}} \pm 109,29$ & $338,40^{b} \pm 118,76$ & $*$ \\
\hline $28-31$ & 3 & $639,28^{a} \pm 154,27$ & $495,76^{b} \pm 180,02$ & $*$ \\
\hline $28-32$ & 4 & $848,20^{\mathrm{a}} \pm 261,27$ & $660,44^{b} \pm 258,59$ & $*$ \\
\hline $28-33$ & 5 & $1043,04^{\mathrm{a}} \pm 321,81$ & $831,64^{b} \pm 309,26$ & $*$ \\
\hline $28-34$ & 6 & $1243,96^{a} \pm 376,52$ & $1010,08^{b} \pm 380,02$ & $*$ \\
\hline $28-35$ & 7 & $1462,24^{\mathrm{a}} \pm 392,95$ & $1180,88^{b} \pm 440,63$ & $*$ \\
\hline $28-36$ & 8 & $1680,28^{a} \pm 407,52$ & $1353,28^{b} \pm 497,22$ & $*$ \\
\hline $28-37$ & 9 & $1923,32^{a} \pm 418,53$ & $1544,36^{b} \pm 542,55$ & $*$ \\
\hline $28-38$ & 10 & $2182,12^{\mathrm{a}} \pm 429,75$ & $1745,28^{b} \pm 573,13$ & $*$ \\
\hline $28-39$ & 11 & $2418,04^{a} \pm 437,87$ & $1953,40^{b} \pm 602,94$ & $*$ \\
\hline $28-40$ & 12 & $2622,16^{\mathrm{a}} \pm 488,90$ & $2169,72^{b} \pm 622,09$ & $*$ \\
\hline
\end{tabular}

Keterangan:

$*$ = berbeda nyata ( $\mathrm{t}$ hitung $>\mathrm{t}$ tabel)

Tabel 6. Rataan ukuran berat telur ayam Ketarras dan ayam Arab selama penelitian

\begin{tabular}{cccc}
\hline \multirow{2}{*}{ Umur (Minggu) } & \multicolumn{2}{c}{ Ukuran Berat Telur } & \multirow{2}{*}{ Keterangan } \\
\cline { 2 - 3 } & P0 (Ayam Ketarras) & P1 (Ayam Arab) & \\
\hline 29 & $\ldots \ldots \ldots \ldots \ldots . .$. & gram $/$ butir $\ldots \ldots \ldots \ldots \ldots \ldots \ldots \ldots \ldots \ldots$ & \\
30 & $44,55^{\mathrm{a}}$ & $38,21^{\mathrm{b}}$ & $*$ \\
31 & $44,90^{\mathrm{a}}$ & $38,71^{\mathrm{b}}$ & $*$ \\
32 & $45,26^{\mathrm{a}}$ & $39,34^{\mathrm{b}}$ & $*$ \\
33 & $45,82^{\mathrm{a}}$ & $40,36^{\mathrm{b}}$ & $*$ \\
34 & $45,95^{\mathrm{a}}$ & $40,76^{\mathrm{b}}$ & $*$ \\
35 & $46,08^{\mathrm{a}}$ & $41,31^{\mathrm{b}}$ & $*$ \\
36 & $46,64^{\mathrm{a}}$ & $41,46^{\mathrm{b}}$ & $*$ \\
37 & $47,82^{\mathrm{a}}$ & $41,84^{\mathrm{b}}$ & $*$ \\
38 & $48,22^{\mathrm{a}}$ & $42,27^{\mathrm{b}}$ & $*$ \\
39 & $48,65^{\mathrm{a}}$ & $42,93^{\mathrm{b}}$ & $*$ \\
40 & $48,34^{\mathrm{a}}$ & $43,36^{\mathrm{b}}$ & $*$ \\
\hline Rataan & $48,14^{\mathrm{a}}$ & $44,33^{\mathrm{b}}$ & $*$ \\
\hline
\end{tabular}

Keterangan:

$*$ = berbeda nyata ( $\mathrm{t}$ hitung $>\mathrm{t}$ tabel) 


\section{Konversi ransum}

Konversi ransum ayam Ketarras dan ayam Arab umur 28 - 40 minggu disajikan pada Tabel 7. Hasil uji t menunjukkan bahwa konversi ransum ayam Ketarras dan ayam Arab berbeda nyata ( $t$ hitung $>\mathrm{t}$ tabel). Konversi ransum kumulatif umur 28 - 40 minggu ayam Ketarras $(3,32)$ lebih rendah dibanding ayam Arab $(3,58)$. Hal ini menunjukkan bahwa efisiensi ransum ayam Ketarras lebih baik dibanding ayam Arab. Menurut Rasyaf (1997), semakin rendah konversi ransum semakin baik, karena ternak lebih efisien dalam menggunakan ransum. Lebih rendahnya konversi ransum pada ayam Ketarras dibanding ayam Arab, disebabkan karena produksi telur ayam Ketarras ( 56,12 butir) lebih tinggi dibandingkan ayam Arab (52,52 butir) (Tabel 4) dengan ukuran berat telur ayam Ketarras (46,7 g/butir) lebih besar dibandingkan ayam Arab (41,24 g/butir) (Tabel 5), sehingga produksi massa telur ayam Ketarras lebih tinggi dibanding ayam Arab.

Jika dibandingkan dengan tetuanya yaitu ayam Arras, Arianto (2018) menyatakan bahwa, konversi ransum ayam Arras $(2,76)$, sedangkan ayam Arab $(4,21)$. Dari pernyataan tersebut dapat diketahui bahwa konversi ransum ayam Ketarras lebih tinggi dibanding ayam Arras, namun juga lebih rendah jika dibandingkan ayam Arab. Hal ini diduga pengaruh dari genetik. Genetik ayam Ketarras adalah $75 \%$ ayam Arab dan $25 \%$ ayam Ras petelur, sedangkan genetik ayam Arras 50\% ayam Ras petelur dan $50 \%$ ayam Arab. Indra et al. (2013) menyatakan bahwa, salah satu faktor yang mempengaruhi konversi ransum adalah genetik..

Tabel 7. Rataan konversi ransum ayam Ketarras dan ayam Arab

\begin{tabular}{ccccc}
\hline $\begin{array}{c}\text { Umur } \\
\text { (Minggu) }\end{array}$ & $\begin{array}{c}\text { Lama } \\
\text { Pengamatan } \\
\text { (Minggu) }\end{array}$ & P0 (Ayam Ketarras) & P1 (Ayam Arab) & Keteranga \\
\cline { 3 - 5 } $28-29$ & 1 & 3,20 & 3,31 & $*$ \\
$28-30$ & 2 & 3,20 & 3,53 & $*$ \\
$28-31$ & 3 & 3,30 & 3,63 & $*$ \\
$28-32$ & 4 & 3,33 & 3,63 & $*$ \\
$28-33$ & 5 & 3,39 & 3,63 & $*$ \\
$28-34$ & 6 & 3,43 & 3,62 & $*$ \\
$28-35$ & 7 & 3,44 & 3,62 & $*$ \\
$28-36$ & 8 & 3,43 & 3,62 & $*$ \\
$28-37$ & 9 & 3,38 & 3,62 & $*$ \\
$28-38$ & 10 & 3,31 & 3,62 & $*$ \\
$28-39$ & 11 & 3,29 & 3,60 & $*$ \\
$28-40$ & 12 & 3,32 & 3,58 & $*$ \\
\hline
\end{tabular}

Keterangan:

$*$ = berbeda nyata ( $\mathrm{t}$ hitung $>\mathrm{t}$ tabel) 


\section{Kesimpulan}

Hasil penelitian dapat disimpulkan bahwa konsumsi ransum dan produksi massa telur serta ukuran berat telur ayam Ketarras umur 28 - 40 minggu lebih tinggi dengan konversi ransum lebih baik dibanding ayam Arab. Produksi telur ayam Ketarras cenderung lebih tinggi meskipun berbeda tidak nyata dibanding dengan ayam Arab.

\section{Daftar Pustaka}

Arianto, S. 2018. Performans produksi telur ayam Arras dan ayam Arab umur 20 sampai 40 minggu. Skripsi. Jurusan Peternakan Fakultas Pertanian Universitas Bengkulu. Bengkulu.

Astuti, M. 2007. Pengantar Ilmu Statistik Untuk Peternakan dan Hewan. Binasti Publisher. Bogor.

Gunawan, E., D. Kaharuddin, dan Kususiyah. 2018. Performans keturunan ayam Arras dengan ayam Arab (ayam Ketarras) umur 2-12 minggu. Jurnal Sain Peternakan Indonesia, 13(1): 89-100.

Hartadi, H.S., Reksohardiprojo dan A.D. Tilman. 2005. Tabel Komposisi Pakan untuk Indonesia. Cetakanke IV. Universitas Gajah Mada.

Indra, G. K., Achmanu, dan A. Nurgiartiningsih. 2013. Performans produksi ayam Arab (Gallus turcicus) berdasarkan warna bulu. Jurnal Ternak Tropika, 14 (1): 814.

Kaharuddin, D., dan Kususiyah. 2011. Pengaruh komposisi genetik hasil persilangan puyuh (Cortunix-cortunix japonica) tiga daerah asal terhadap performans produksi telur. Laporan penelitian. Universitas Bengkulu. Bengkulu.

Kaharuddin, D., Kususiyah, dan M. A. Saputra. 2020. Performa fase awal produksi pada ayam Ketarras dan ayam Arab. Buletin Peternakan Tropis. 1(1) : 2534.

Kartasudjana, R. dan E. Suprijatna. 2006. Manajemen Ternak Unggas. Penebar Swadaya.

National Research Council. 1994. Nutrient Requirement of Poultry. Ninth Revised Edition. Printing and Publishing National Academy of Science. Washington.

North, M. O. 1984. Commercial Chicken Production Manual. AVI Publishing, Inc. Wesport, Connecticut.

Rasyaf, M. 1997. Penyajian Makanan Ayam Petelur. Kanisius. Jakarta.

Kartasudjana, R. dan E. Suprijatna. 2006. Manajemen Ternak Unggas. Penebar Swadaya.

National Research Council. 1994. Nutrient Requirement of Poultry. Ninth Revised Edition. Printing and Publishing National Academy of Science. Washington.

North, M. O. 1984. Commercial Chicken Production Manual. AVI Publishing, Inc. Wesport, Connecticut.

Rasyaf, M. 1997. Penyajian Makanan Ayam Petelur. Kanisius. Jakarta. 